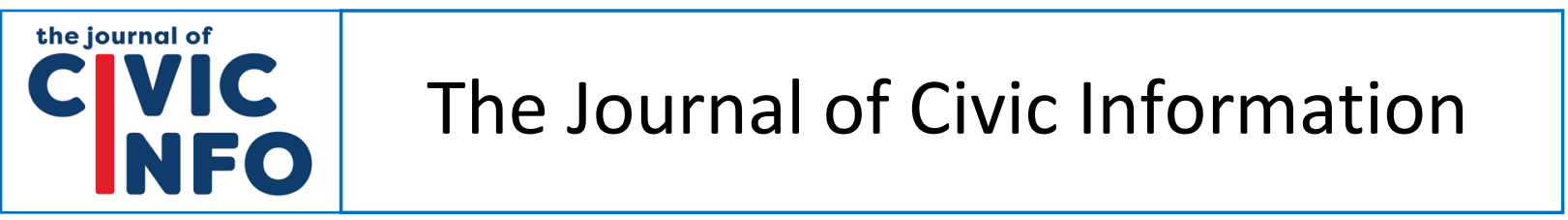

Volume 2 | Number 2

October 2020

Journal homepage: https://journals.flvc.org/civic/

ISSN (online): 2641-970X

\title{
Freedom of Information Audits as Access Advocacy
}

\author{
Kevin Walby \& Jeff Yaremko *
}

\author{
Article Information \\ Received: July 8, 2020 \\ Accepted: Aug. 24, 2020 \\ Published: October 31, 2020 \\ Keywords \\ Freedom of information \\ Public records \\ Government transparency \\ Audits \\ Access advocacy
}

\begin{abstract}
To evaluate the performance of FOI regimes, associations of journalists and other groups undertake FOI audits. These audits assess the depth of disclosure, the use of exemptions, among other indicators of the health of FOI laws. Drawing on a thematic analysis of FOI audits, we examine how these audits are conducted and what the audits reveal about FOI in multiple jurisdictions. We discern four themes in these audits: (1) law enforcement and security hindrance of FOI, (2) a link between FOI advocacy and struggles for government transparency, (3) gross abuses of FOI, and (4) the potential for social change. Arguing that FOI audits are a form of access advocacy, we suggest future FOI audits could be more community-based and participatory. We also provide recommendations for those undertaking future FOI audits.
\end{abstract}

* Kevin Walby, Department of Criminal Justice, University of Winnipeg; Jeff Yaremko, Independent Researcher. Please send correspondence about this article to Kevin Walby at k.walby@uwinnipeg.ca.

Acknowledgements: The authors thank the editor, the reviewers, and Chris Hurl for their insightful comments on earlier drafts of this paper.

To cite this article in Bluebook style: Kevin Walby \& Jeff Yaremko, Freedom of Information Audits as Access Advocacy, 2(2) J. CIVIC INFO 22 (2020).

To cite this article in APA style: Walby, K., \& Yaremko, J. (2020). Freedom of Information Audits as Access Advocacy. Journal of Civic Information, 2(2), 22-42.

DOI: https://doi.org/10.32473/joci.v2i2.126523

Published under Creative Commons License CC BY-NC, Attribution NonCommercial 4.0 International. 


\section{Introduction}

Even for Western nations that are thought to be open and democratic, government secrecy has posed a significant problem in recent years (Aldrich \& Moran, 2019; Potolsky, 2019; Luscombe \& Walby, 2017). Freedom of information (FOI) laws have been enacted around the world as a means of granting citizens access to government records, such as draft reports, internal statistics, and even emails of government workers. Citizens are entitled to public records and information on government activities, politician salaries, varied statistics, among others. Some FOI laws provide access to more types or classes of records than others (Martin \& Lanosga, 2010; Michener, 2011; Mulvey \& Valvo, 2019). FOI has often been used by investigative journalists in shining light on abuses of power in government (Cuillier, 2019). FOI is also important for social science research (Brownlee, 2015; Sheaff, 2019), especially in sociology and criminology. For those involved in public interest journalism and critical research, there are simply no other ways to access some of these records. Yet as Birkinshaw (2010) notes, the actuality of FOI practice and administration often diverges from the spirit of the law. While the enactment of an FOI law is often celebrated as a watershed moment for transparency, compliance does not typically match the ideal (Darch \& Underwood, 2005). The challenges in confronting secrecy are precipitous. It therefore remains important to conduct research on FOI and to perform audits of how well FOI regimes are working.

FOI audits help researchers to investigate government conduct. FOI audits entail an investigation into government transparency based on the systematic submission of FOI or public record requests and the analysis and comparison of outcomes and disclosures. There is a history of FOI audits that overlaps with social science research. For example, Ralph Nader (1970) had dozens of FOI users submit requests on a variety of topics, and then assessed the results. Nader concluded already in 1970 that government agencies across the United States were not complying with the letter of FOI law. News media organizations, watchdog organizations, university groups, and arms-length government bodies have since undertaken FOI audits for different reasons. Some audits are annual, others are intermittent. There is also related literature on FOI in comparative context that involves an audit component and compares levels of compliance and performance (Hazell \& Worthy, 2010). FOI research that incorporates an audit component tells us something about how government agencies relate to FOI law and FOI users, but also reveals patterns in how FOI regimes function and change over time. Contributing to international literature on FOI and government transparency (Capeloto, 2014; Cuillier \& Pinkleton, 2011; Grimmelikhuijsen et al., 2018; Wasike, 2016; Worthy et al., 2017), we assess FOI audits performed by journalism agencies as well as access advocacy groups to assess how these audits are designed and what trends appear. By examining trends in FOI audits, we hope to further reveal their importance as a form of research but also as a way of advocating for citizens and social change through identifying and addressing problems with FOI regimes and other government processes.

First, we review relevant literature on FOI performance and compliance by governments as well as literature on FOI audits. We situate FOI audits as one of a number of kinds of investigations that fit the definition of audits of government processes (e.g., Kells, 2010). Second, we discuss the parameters of our search and the characteristics of the audits we analyzed. Third, we examine four themes apparent in how these audits are performed and what the audits reveal about the functioning of FOI laws. Law enforcement and security are used in multiple jurisdictions to block access to government records, even when the notion of public interest is invoked. Audits are described as fulfilling an important role in providing transparency and accountability. There 
are many continuing abuses of power and process in governments discovered or highlighted by FOI audits. As well, some FOI audits lead to social change. Arguing that FOI audits are a form of access advocacy, we conclude with a discussion of what our findings mean for the literature on FOI and information rights and activism. We suggest that future FOI audits could be more participatory, which will enrich the audit by shaping the audit's request wording and by boosting the connection to struggles for social justice. Finally, we provide recommendations for those undertaking FOI audits in the future.

\section{Context and relevant literature}

FOI is notable as a research tool used by a wide range of professionals and scholars from a variety of backgrounds, including sociology, political science, law, and journalism. It also cuts across government institutions in ways that few other laws or policies do. Ackerman and SandovalBallesteros (2006) trace the rise of FOI worldwide, which they refer to as an explosion of records laws and right to information movements. Challenges remain in accessing government records. In Canada at the federal level, the Access to Information Act has also become less efficacious over time due to a number of amendments and administrative regressions as well as lack of resources (Roziere \& Walby, 2020; Roberts, 2006). There are ways that FOI can be undermined from inside government if the promotion of access to information is not accepted throughout (Elliot \& Thomas, 2018; Roberts, 2006, 2002). Despite more training and professionalization of FOI coordinators (Kimball, 2011), there are many ways that political workers and even non-partisan bureaucrats undermine FOI and the disclosure of government records (Gilbert, 2000). FOI office coordinators face challenges in meeting the requirements of FOI law and the demands of FOI users (Shepherd et al., 2010). The relationship between FOI users and FOI coordinators can be antagonistic (Kimball, 2012). Johnson (2020) found FOI coordinators to be paternalistic, which can translate into an attitude that promotes professionalism over transparency.

When FOI compliance is low or when abuses of FOI laws are discovered, there are few remedies other than appealing to an FOI Commissioner/Ombudsperson, an administrative tribunal, a judicial tribunal, or the courts (Phillips \& Dill, 2019; Yeager, 2006; Rowat, 1993). Digital, online access to records or digital pre-emptive disclosure can provide more access to records, though this may not boost perceptions of government transparency (Capeloto, 2019). FOI is one of the only mechanisms for access, but this assumes the records are there in the first place. Destruction of records (Banton, 2012) or failure to produce records to begin with is a large problem in government but is not something that an FOI audit would detect. There is also an emerging FOI industry (Goldberg, 2006) comprised of paid access advocates and technology companies that aim to promote transparency as a kind of product rather than a movement or a means to justice (also see Capeloto, 2014).

FOI compliance is part of a bigger story regarding the relationship between information, the state, and citizens. Given the drastic differences in political and administrative cultures and funding for government transparency initiatives, Michener (2015) notes how it is difficult to compare FOI performance and compliance from one country to the next. There is variability as it regards different classes of records and different areas of government. Almanzar et al. (2018) show that FOI disclosures for security-related records are released at lower rates with less depth of disclosure. There is also variability in FOI performance depending on size of government agency, awareness of the technicalities of FOI, and ideology of government leaders (Saez-Martin et al., 2017). Looking at data on FOI performance and compliance in Mexico, Lagunes and Pocasangre 
(2019) show that performance and compliance improved between 2005-2015, though a number of regressive tendencies such as lack of depth of disclosure and lack of duty to assist also emerged. Guy and Oberlin (2009) use FOI audits conducted by the National Security Archive in the USA to examine the performance of FOI and compliance with FOI law by various government agencies. Our approach is similar, though we include additional audits performed by investigative journalists and other access advocates. Our focus is less on compliance with FOI law and more on the themes appearing in the audits.

Some social science and journalism studies using field experiments have further investigated access regimes and FOI performance. These methodologies have an audit component built into them. For example, Koch (2019) conducted a field experiment to assess whether identity or status of the FOI user was a factor in response time and depth of disclosure by the Danish municipal agencies that the FOI requests were sent to. The author found no evidence of bias, but notes that these findings cannot be generalized to other jurisdictions. Koch calls for more research using FOI field experiments and research on FOI compliance through audit-type research designs. Cuillier (2010) has conducted important field experiments on the effects of different tactics that FOI users can use to assess whether these boost compliance by FOI offices or not. In this sense, social science research on FOI can incorporate an audit component, which can result in valuable findings on FOI performance. With this understanding of the variation of audit design in mind, below we explore the following questions. How have FOI audits been organized? What are the main findings of these FOI audits? How can FOI audits be used to encourage public awareness of the problem of government secrecy and to foster information advocacy and activism? By answering these questions we aim to contribute to multi-disciplinary literature on FOI as well as literatures on information rights and activism.

\section{Method}

We were aware of the annual FOI audits such as the National Security Archive's FOI audits and the News Media Canada's FOI audits. To extend our sample, we continued searching for audits published since 1999. We searched largely for audits conducted by groups outside of university settings and searched primarily for audits conducted in conjunction with journalism associations. However, some of the audits we located are not linked with journalism associations. These audits take the form of published reports with appendices. We did not reject audits based on political or normative stance taken. We wanted to focus on a diverse sample, rather than recounting all the annual (and more well known) audits in their entirety. We arrived at a sample of 29 audits for analysis in this paper (see list starting on page 27). This sample allows us to assess and compare FOI audits from Canada, the United States, the United Kingdom, and other countries. We acknowledge that we have not analyzed all FOI audits appearing between 1999-2020, which is one limit of this study. We conducted a thematic analysis of these audits (Braun \& Clarke, 2019). Thematic analysis allows for patterns, trends, and commonalities to be located in a number of texts. Each audit was scrutinized for commonalities, differences, and distinguishable moments, with four main themes emerging: (1) law enforcement and security hindrance of FOI, (2) a link between FOI advocacy and struggles for government transparency, (3) gross abuses of FOI, and (4) the potential for social change. 


\section{FOI audits in context}

We found several common characteristics, methods, and themes across the FOI audits. Governments and their departments are targeted for these types of audits by large annual audits such as News Media Canada's FOI audits on the Canadian federal, provincial, and municipal governments or the National Security Archive's FOI audits on the United States federal government. However, depending on which agencies are added to the schedule of the Act in any jurisdiction, a number of other organizations such as nonprofits and universities could also be sent FOI requests that they would be required to respond to.

The most common foci of FOI audits are timeliness of responses to the FOI requests, fees charged for search and disclosure, amount of information disclosed, number of requests responded to, and the compliance with FOI laws. These foci are prevalent throughout audits internationally. The News Media Canada FOI audits from 2005 to 2017 assessed these factors on an annual basis with expanded focuses and analyses year by year. The News Media Canada and Canadian Newspaper Association FOI audits were recognized by newspapers, magazines, national broadcasts, and radio interviews across Canada (News Media Canada FOI Audit, 2005). These FOI audits highlight gaps, performance issues, and inconsistencies with FOI compliance and timeliness in Canada's federal, provincial, and municipal FOI systems, as well as areas of improvement for adequate information access for citizens. Michael McEvoy (2018) also focused on these issues in an audit of British Columbia's City of White Rock in 2018, where the goal was to ensure that the City of White Rock was complying with the FOI requests submitted under the Freedom of Information and Protection of Privacy Act. Organizations in the United States such as the National Security Archive, the New Mexico Press Association, the Tennessee Coalition for Open Government, and the Des Moines Register in Iowa, among others, have undertaken audits looking at different levels of governments using comparable foci. FOI audit reports throughout the United Kingdom, Australia, and Mexico also focus on disclosure, compliance, fees, and timeliness.

Additional factors assessed in audits include the need for releasing records in machinereadable formats, the requirement for identification, building security compliance with those requesting public records, and biased treatment of some FOI users (Fisher et al., 2018; Georgia Audit, 2004; Hammitt, 2001). The identification requirement along with the building security compliance factor were found to be of common concern for FOI requesters in the Tennessee, Connecticut, and New Mexico audits. Surveyors and requesters were required to provide their name, driver's license, and the reason they were wanting to view the records, and there were various other roadblocks for those seeking public records (Fisher et al., 2018; Hammitt, 2001; Massey, 2000). The "average person" and "influential figure" approach was also used in Lagunes and Pocasangre's FOI audit of compliance with Mexico's FOI Act. This audit analyzed the disclosure, compliance, fees, and timeliness factors by sending FOI requests by an "average person" and an "influential figure," then investigated for any potential biased treatment between the two groups (Lagunes \& Pocasangre, 2019).

FOI audits can also highlight improvement or regression within FOI regimes over time. For example, governments are required to respond to FOI requests from citizens within legislated timelines (such as 30 days), but government bodies can issue an extension. Assessing the time to disclosure as well as analyzing the obstacles that hinder timely access to records were common objectives of FOI audits (Fisher et al., 2018). Examples of this can be seen in the National Security Archive audits, with audit variations such as "the ten oldest pending FOIA requests," where FOI request backlogs dating back to the late 1980s were analyzed (Blanton et al., 2004). This type of 
audit reveals backlogs and neglected requests throughout a number of federal agencies. Since the early 2000s, several FOI audits have also tested agencies on their use of technologies and online systems. An example includes the National Security Archive and their 2007 and 2015 audits focusing on online information in relation to the 1997 Electronic Freedom of Information Act amendments (Blanton et al., 2007; Jones \& Harper, 2015). The 2013-2014 FOI audit by News Media Canada focused on electronic and open data (Vallance-Jones, 2014). We now turn to an analysis of the main themes we encountered in these audits.

Table 1: Audits grouped by main themes

(Links provided to available files, and provided in reference list at end)

\begin{tabular}{|c|c|}
\hline Trends & Audits \\
\hline \multirow{7}{*}{$\begin{array}{l}\text { FOI, Security, and } \\
\text { Law Enforcement }\end{array}$} & - Iowa Audit 2005 \\
\hline & - State Agency FOI Compliance in Connecticut \\
\hline & - New Mexico Public Records Access Audit 2000 \\
\hline & - FOI Hawai'i Audit 2006 \\
\hline & $\begin{array}{l}\text { - Californians Aware FOI Audits - "2007 Law Enforcement Audit Follow } \\
\text { up" and "2011 State Agency Follow-up Audit" }\end{array}$ \\
\hline & $\begin{array}{l}\text { - News Media Canada FOI Audits - “2015 FOI Audit” and “2017 FOI } \\
\text { Audit” }\end{array}$ \\
\hline & $\begin{array}{l}\text { - The National Security Archive FOI Audits - “The Ashcroft Memo } \\
\text { (2003)," “Justice Delayed is Justice Denied (2003)," “Eight Federal } \\
\text { Agencies Have FOIA Requests a Decade Old (2011)," and “25-Year-Old } \\
\text { FOIA Request Confirms FOIA Delays Continue Unabated (2019)" }\end{array}$ \\
\hline \multirow{17}{*}{$\begin{array}{l}\text { FOI Advocacy, } \\
\text { Rights, and } \\
\text { Awareness }\end{array}$} & - Tennessee Public Records Policy Audit 2017-2018 \\
\hline & - OIPC Audit and Compliance Report 2018 (City of White Rock) \\
\hline & - Administration of the FOI Act 1982 in Australia \\
\hline & - Iowa Audit 2005 \\
\hline & - $\quad$ ECT Audit in England, 2011-2015 \\
\hline & - State Agency FOI Compliance in Connecticut \\
\hline & - Audit of Access to Information at the Canadian Space Agency 2018 \\
\hline & - Canadian Border Services Agency Audit 2016 \\
\hline & - New Mexico Public Records Access Audit 2000 \\
\hline & - Medicines and Healthcare Products Regulatory Agency FOI Audit, UK \\
\hline & - $\quad$ FOI Hawai'i Audit 2006 \\
\hline & - Employment and Social Development Canada 2015-2016 Audit \\
\hline & - Audit of Mexico's FOI Act \\
\hline & - Californians Aware FOI Audits \\
\hline & - $\quad$ City of Vancouver FOI Audit 2016 \\
\hline & - News Media Canada FOI Audits \\
\hline & - The National Security Archive FOI Audits \\
\hline
\end{tabular}




\begin{tabular}{|c|c|}
\hline \multirow{7}{*}{ FOI Abuses } & - Iowa Audit 2005 \\
\hline & - Georgia Audit 2004 \\
\hline & - State Agency FOI Compliance in Connecticut \\
\hline & - Audit of Mexico's FOl Act \\
\hline & - City of Vancouver FOI Audit 2016 \\
\hline & - News Media Canada FOI Audits - “2009-2010 FOI Audit” \\
\hline & $\begin{array}{l}\text { - The National Security Archive FOI Audits - "Justice Delayed is Justice } \\
\text { Denied (2003)," "An FOIA Request Celebrates its } 17^{\text {th }} \text { Birthday (2006)," } \\
\text { and "25-Year-OId FOIA Request Confirms FOIA Delays Continue } \\
\text { Unabated (2019)," and "How Transparent is President Trump? (2020)" }\end{array}$ \\
\hline \multirow{7}{*}{$\begin{array}{l}\text { FOI Audits and } \\
\text { Social Change }\end{array}$} & - Iowa Audit 2005 \\
\hline & - Administration of the FOI Act 1982 in Australia \\
\hline & $\begin{array}{l}\text { - Californians Aware FOI Audits - “2007 Law Enforcement Audit Follow } \\
\text { up” }\end{array}$ \\
\hline & - News Media Canada FOI Audits \\
\hline & - City of Vancouver FOI Audit 2016 \\
\hline & - City of White Rock FOI Audit \\
\hline & - The National Security Archive FOI Audits \\
\hline
\end{tabular}

Law enforcement, security, and FOI

The first theme in the FOI audits is the terse relationship between law enforcement, security and FOI. Law enforcement and security agencies have often been found to be the worst performers in terms of access to information. There has been frequent resistance to information access for those attempting FOI requests, especially in the United States. In the United States, there have been incidences with use of force, interrogation, denying entrance, and threats by the building security or law enforcement officials against those (citizens and surveyors) attempting to gain access to public information by the building security or law enforcement officials. These types of occurrences were observed in (but not limited to) Connecticut, Iowa, and New Mexico (Hammitt, 2001; Massey, 2000). Indeed, Krantz et al. (2005) recognized that law enforcement officials can be "overly cautious" and the agencies can "breed secrecy" due to the belief that the public is better served in secrecy. This observation was in regard to an FOI audit undertaken in counties throughout Iowa that included law enforcement agencies and school districts. Additionally, in the 2007 and 2011 audits by Californians Aware, the security was observed to have failed in understanding FOI guidelines and had a "general ignorance" to public record laws with several law enforcement agencies noted as being well below norms (Public Access to Law Enforcement Information, 2007; State Agencies Audit, 2011). This lack of awareness of FOI Acts, guidelines, and procedures as well as the need for improved training in FOI controls was found to be widespread throughout the different FOI audits. In a 2016 internal audit, the Canadian Border Services Agency found insufficient training in FOI systems for staff members (Audit of Access to Information and Privacy, 2016). There can also be a culture of secrecy, as observed with the 
general lack of transparency of the federal government in Canada and the Ashcroft Memorandum in the United States.

In the United States, the Ashcroft Memorandum released on October 12, 2001, contributed to heightened secrecy and problems with accessing public records. After the events of 9/11, government secrecy rose dramatically, and security measures increased substantially under the administration led by President George Bush. A month after the 9/11 attacks, Attorney General John Ashcroft's FOI Act Memorandum allowed government agencies to withhold records more easily with the assistance of the Department of Justice (Blanton et al., 2003). This memorandum emphasized the protection of "fundamental values," including national security, law enforcement agency effectiveness, personal privacy, and sensitive business information (Ashcroft, 2001). Based on the protection of these "fundamental values," government agencies were encouraged to withhold information and public records from citizens. In 2008, President Bush's executive order called for a "citizen-centered" and "results orientated" federal FOI system. The National Security Archive's 2008 federal FOI audit revealed that there were only limited improvements provided by the executive order, with no changes or improvements in some agencies. The National Security Archive audits found some improvements after President Obama's FOI openness orders in their 2011 federal audit after President Obama's FOI openness order, despite some agencies still noted to be lagging. However, another 2011 audit by the National Security Archive found that several U.S. agencies, including the Army, Central Intelligence Agency, Department of Justice, Department of State, Drug Enforcement Agency, and the Transportation Security Administration (among others), still failed to comply by addressing the many backlogged requests. These denials and non-responses opened the door to legal action for the National Security Archive (Blanton \& Jones, 2011a, 2011b; Blanton et al., 2008), advocating for greater access.

At the state and county levels in the United States, FOI audits have uncovered resistance to information disclosure and transparency from police forces in several states. Barry Massey notes how police forces and law enforcement agencies throughout New Mexico were the worst performers in releasing public records (Massey, 2000). In Iowa, Colleen Krantz describes requests to police forces being denied and threats against the requesters, including a threat of arrest because a requester did not provide their personal information for the request. By law, requesters in Iowa were not required to respond after requesting public records (Krantz et al., 2005). Similarly, a surveyor who was requesting information in the 2001 Connecticut audit was detained by a vigilante victim advocate who threatened that the police would be involved (Hammitt, 2001). This incident in Connecticut will be discussed in the "Abuses to FOI" section. FOI audits assist in revealing these types of mistreatments toward taxpayers who have a right to view the public records.

In the Canadian context, the 2017 national FOI audit performed by Vallance-Jones and Emily Kitagawa (2017) mentioned that the Royal Canadian Mounted Police and National Defence failed to respond to any requests by the end of the audit, while the Canada Border Services Agency (CBSA) had only responded to only one out of five requests. The 2015 FOI audit by VallanceJones and Kitagawa focused on police forces throughout Canada, noting that municipal police forces were the least transparent public bodies. Police forces across Canada as a whole were pinpointed as being reluctant to release information for the 2015 audit, with municipal police forces recognized as the overall least transparent public agencies in 2015. According to VallanceJones and Kitagawa (2015), the Saskatoon, Regina, and Charlottetown police forces had refused any access to information because at the time police forces were not included in the Saskatchewan and Prince Edward Island FOI legislation, further displaying how law enforcement and security 
agencies can often be the worst violators in complying with FOI laws and guidelines. Through various forms of access advocacy since, those police agencies have been brought under FOI legislation. Law enforcement and security agencies that continue to deny citizens' rights to information access may begin to lose public trust over time.

FOI advocacy, rights, and awareness

The second theme in the FOI audits is the relationship between FOI, information rights, and awareness of transparency. FOI audits frequently involve different forms of advocacy, protecting citizens' rights, and raising awareness of those rights. As noted, FOI audits are often conducted by watchdog organizations, university groups, news media organizations, and different government bodies. Examples of watchdog organizations include the Tennessee Coalition for Open Government, the New Mexico Foundation for Open Government, the Society of Professional Journalists, Californians Aware, and the National Security Archive. These examples of watchdog organizations consist of access advocates who assist in and lead the execution of different FOI audits, among the organizations' other functions.

The common goals of these different FOI audits are to advocate for easier and enhanced access to public records for citizen requesters, government transparency and accountability, as well as ensuring the lawful compliance to information requests (Fisher et al., 2018; McEvoy, 2018). This even includes the University of East Anglia's Climate Research Unit's failure to comply with information requests from climate change skeptics such as Stephen McIntyre from the "climate audit," as noted by the Science and Technology Select Committee. The Science and Technology Committee criticized the University of East Anglia for misconduct with FOI requests and for supporting the Climate Research Unit in withholding information from climate change skeptics. The director and scientists of the Climate Research Unit viewed the requests from McIntyre and his followers as time consuming, overwhelming, and disruptive to their research. Yet, the Science and Technology Committee noted that the reputation of climate science could have been harmed by the lack of disclosure from the Climate Research Unit. McIntyre claimed that he wanted data to be publicly available (Cosh, 2009; Disclosure of Climate Data from the Climate Research Unit, 2010; Heffernan, 2009).

A general ignorance of FOI requirements on the part of government officials was noted in several audits. The report on the 2006 Hawai'i audit by the Society of Professional Journalists advised that average citizens should not need to keep returning to obtain the information that was requested, as the information should be released during the first visit and citizens should not require their identification as well as the reason they want to view the public records to be scrutinized (Freedom of Information Compliance Audit, 2006). If security personnel are denying entrance to individuals seeking access to public records, then there are competing interests that arise in administering the FOI Act (Hammitt, 2001). Krantz et al. (2005) recognized the need for more training to raise awareness on FOI/open-record rights, laws, and policies. While there can be frequent roadblocks and difficulties in accessing public information, the audits also detect various forms of access advocacy. The Gwinnett Daily Post stated that taxpayers are entitled to the access of public records and information, and that public officials' jobs are to serve the people efficiently, willingly, and completely (Georgia Audit, 2004).

Whether someone is "influential," a journalist, or an "average" citizen, requesters should be treated equally throughout the FOI request and disclosure process. This has been tested in several cases. The Georgia audit in 2004 by the Gwinnett Daily Post tested for unequal response 
times of requests between an "average joe" and a reporter (Georgia Audit, 2004). The 2016 audit on the City of Vancouver also found media requesters to be treated differently and given "special treatment" compared to other applicants (Lupick, 2016). Lagunes and Pocasangre's (2019) audit of Mexico found that the "average" and "influential" groups were treated equally, regardless of political and socioeconomic status. Furthermore, the 2006 Hawai'i audit utilized citizen volunteers to evade any biased treatment toward journalists (Freedom of Information Compliance Audit, 2006). Several other FOI audits involved a participatory approach, including the 2000 New Mexico audit, the 2005 Iowa audit, the (Californians Aware) 2009 Sacramento Public Education Audit, and the Tennessee Public Records Policy audit in 2018. These audits utilized the participation of journalism students, civic groups (such as League of Women Voters), and citizen volunteers. The narratives of the participants were often highlighted within an audit's report (Massey, 2000). This participatory approach was used to avoid favorable treatment toward journalists (Freedom of Information Compliance Audit, 2006). While seeking to avoid biased treatment toward journalists, the citizens and students volunteering can learn more about the laws and their rights regarding access to information and FOI.

Proper systems, policies, guidelines, and frameworks need to be in place for FOI compliance to be heightened. The Canadian Space Agency and CBSA were audited to determine if their information management systems met the FOI and access to information requirements (Audit of Access to Information at the Canadian Space Agency, 2018; Audit of Access to Information and Privacy, 2016). In the last three decades, both the Conservative Party and Liberal Party have claimed during campaigns that they will be the more transparent and accountable governments. The 2006 News Media Canada FOI audit observed the federal conservative government as being one of the worst performers, despite the conservatives' campaign promises of transparency and accountability (News Media Canada FOI Audit, 2006). Similarly, Justin Trudeau's Liberal campaign featured promises of transparency, yet the findings of the 2017 national audit by Vallance-Jones and Kitagawa (2017) revealed a worse FOI performance by the Trudeau government than the previous Harper government. The federal government was given a letter grade of " $F$ " for the lack of disclosure in 2017. Jim Bronskill (2017) noted how the audit found "trouble spots" throughout municipal, provincial, and territorial levels of government, regarding the federal system as incredibly "gummed up." From 2005 onward, the News Media Canada (and Canadian Newspaper Association) audits have aimed to expand public awareness about the condition of the Canadian FOI system and have consistently achieved national coverage.

In Mexico, Human Rights Watch recognized the FOI Act enacted in 2002 as an "unambiguous achievement." Lagunes and Pocasangre (2017) noted that the FOI Act can be a tool for unearthing corruption in the Mexican government. Indeed, the FOI Act has uncovered cases of corruption in Mexico. Independent FOI audits such as Lagunes and Pocasangre's FOI audit of the Mexican government help to ensure that the FOI act is effective and that agencies are complying with it. This is also the case for FOI audits elsewhere. In England, an FOI audit report on the use of electroconvulsive therapy (ECT) by John Read et al. (2018) mentioned that national audits should be re-established and that independent monitoring (on ECT outcomes in this particular case) is needed. Nonetheless, independent monitoring is crucial for holding agencies accountable as well as creating transparency of the agencies. Massey stated that citizens can sue if denied the requested public records, with entitlement to court fees, attorney fees, and damages if they win (Massey, 2000). Denials and non-responses to requests opened the doors to legal action for the National Security Archive in 2011 against several U.S. agencies (Blanton and Jones, 2011a). 
FOI audits allow access advocates to test FOI acts, policies, and guidelines that are in place for citizens to access public records. The National Security Archive stated that the U.S. government should consider compliance with the law as a "duty to American democracy" (Elias et al., 2006). In an audit on the Medicines and Healthcare Products Regulatory Agency in the United Kingdom, Grigg et al. (2019) advised how transparency can be improved if every FOI request and response was made available to the public. Moreover, the Australian National Audit Office referred to a recommendation from the Belcher Red Tape Reviews noting that there should be minimal burden and active publication of information in the government entities' practices in Australia (Administration of the Freedom of Information Act, 1982). In an audit-based study of the government of Mexico, Lagunes and Pocasangre (2017) discussed how the Mexican government should invest in improving the management of information and provide government entities with more resources to maintain transparency. In addition, McEvoy's (2018) report on the City of White Rock audit recommended for governments such as the City of White Rock to provide the full documentation of every FOI request, forward requests to departments to find the records speedily, and provide responses to FOI requests within legislated timelines without delay. Ensuring that FOI requests and responses are publicly available can increase transparency and openness (Grigg et al., 2019). Therefore, FOI audits are significant across international boundaries for ensuring the transparency and openness of governments and to assist in protecting citizens against abuses of power and corruption.

\section{Abuses of FOI systems}

The third major theme in the FOI audits is the revelation of abuses of FOI systems, and patterns in these abuses across jurisdictions. There can be instances during FOI audits when rules and guidelines are ignored by or unknown to those responding to FOI users. This can lead to different abuses of FOI and access to information. We found cases where citizens or surveyors wanting to gain access to public records were harassed, intimidated, threatened or interrogated by building security or public officials (Hammitt, 2001; Krantz et al., 2005). One example of this was described in the 2001 Connecticut audit, where a surveyor for the audit who requested the attendance records of a victim advocate named James Papillo was approached by Papillo himself. Hammitt (2001) noted how the surveyor was questioned by the victim advocate, then grabbed while being called "full of shit." The victim advocate also threatened to call the police on the surveyor. This type of ignorance of FOI laws and bullying behavior toward a surveyor in the Connecticut audit was not an isolated case. In the same audit, building security was also found to be denying the surveyors' rights to view certain public records and denying entrance of surveyors. The 2001 FOI audit in Connecticut uncovered these types of problematic findings after the events of 9/11 and the Oklahoma bombings which (in part) led to more stringent security. Hammitt (2001) noted that the statutory rights provided by the law were disregarded by building security with requesters not allowed access past the lobby or being denied entrance altogether, which hindered access to public records.

The National Security Archive has observed different abuses, such as the dramatic increase in government secrecy since the events of 9/11 and U.S. agencies having pending requests that are over a decade or two old (dating back to the 1980s and 1990s). As noted, government secrecy, security, and enforcement became increasingly prevalent after the startling events in New York on September 11, 2001. The administration during the events of 9/11 allowed for the Ashcroft Memorandum to undermine the FOI Act and encouraged more influence for U.S. agencies over 
Freedom of Information Act systems (Blanton et al., 2003). In addition, federal agencies were found to have request backlogs that were highly troublesome. An example of a backlogged request found in the second phase of the 2003 audit included a pending request to the Department of Defense in 1989 that was from a graduate student who became a professor while still awaiting a response. Another pending request that was sent in 1987 was from a reporter named Seth Rosenfield regarding FBI activities. In a follow-up audit in 2007, many of these dated requests remained unfulfilled and incomplete. In 2019, the National Security Archive once again analyzed the U.S. agencies' oldest pending requests dating back to the 1990s and early 2000s, highlighting the problematic backlogs that were not resolved (Blanton et al., 2003; Harper et al., 2019; Nielson, 2007). Additionally, the National Security Archive had been tracking progress in compliance during different presidencies since 2003. An audit by the National Security Archive in 2020 assessed President Donald Trump's pro-transparency and pro-secrecy decisions since his presidency, with decisions such as making phone calls private, keeping his tax returns secret, and classifying the coronavirus talks. Through their audit, the National Security Archive found that President Trump made three times as many pro-secrecy decisions compared to pro-transparency decisions since 2017 (Harper \& Harvey, 2020).

In other cases, there may have been biased treatment toward citizens and reporters making requests. Biased treatment was observed in the 2004 Georgia Audit, for example (Georgia Audit, 2004). The Gwinnett Daily Post recognized roadblocks and difficulties for the "average Joe" in accessing public information in several Georgian cities. In particular, the mayor's son in the City of Norcross experienced these difficulties when requesting access to information on how much money the city had spent on attorney fees, whereas reporters had an easier time accessing the same information. Reporters from the Gwinnett Daily Post had sent similar requests (as the requests sent by the mayor's son) to several government departments. The information requested by the mayor's son was sent to the Post, while the mayor's son (recognized as an "average Joe") was still waiting on the information (Georgia Audit, 2004). As mentioned, an audit conducted in Mexico by Lagunes and Pocasangre (2017) with a similar experimental test had shown opposite results with relatively equal treatment between "influential figures" and "average citizens" (but also see Carroll, 2016).

Making access to public records more difficult for citizens can deter and discourage requesters from wanting to go through the process. Fee charges have been observed to be subject to abuse when attempting to access public records. Lagunes and Pocasangre (2017) noted that the fee charges in Mexico have been trending upwards and fee charges have been placed on requests sporadically and strategically, which was found to be suspicious and burdensome. Their audit of Mexican government agencies found fees to be placed strategically for the purpose of discouraging requesters from seeking certain public records and information (also see Kingston et al., 2018; Wagner, 2017). In an outrageous case, the 2009-2010 FOI audit conducted by News Media Canada observed how British Columbia's Ministry of Transportation was charging $\$ 98,603$ for an FOI request on how much the agency had spent on cell phones (News Media Canada, 2010). In another instance, Lupick (2016) mentioned how the 2016 audit of the City of Vancouver found concerns over the "alleged deletion of records and evasion of FOI laws," as well as city staff allegedly instructed to change naming conventions to make public records more difficult to find. At the time of the report, the City of Vancouver offered an investigation into these issues if the Office of the Information and Privacy Commissioner of B.C. provided further detail and findings. Certain governments and their agencies may take different measures to deter citizens' access to 
information, including actions that disregard FOI laws. Overall, FOI audits assist in uncovering abuses of FOI that can be obstacles to information access and transparency.

\section{FOI audits and social change}

The final theme is societal change emerging as a result of FOI audits. In many cases, FOI audits provide a method to maintain pressure on government agencies to improve FOI regimes or create social change more broadly. The National Security Archive demonstrates this through yearly FOI audits focusing on the compliance of U.S. government agencies. The audits conducted by the National Security Archive in 2008, 2010, and 2011 focus on changes to information accessibility under President Bush (in 2008) and President Obama (in 2010 and 2011), tracking improvements and shortcomings in agency compliance. The National Security Archive also monitored the changes and guidance provided to agencies by President Bush's executive order as well as President Obama's 2009 memoranda for open government. As mentioned, agency compliance was found to be improved in the 2011 audit report compared to the 2010 audit report, with early improvements to the law in the Obama administration compared to previous administrations (Blanton, 2010; Blanton et al., 2008; Blanton \& Jones, 2011b; but see Arnold, 2015). The National Security Archive works toward change through publishing results from these audits and continuously monitoring government approaches to the law and information accessibility.

Krantz et al. (2005) notes how a reporter (who was attempting to request public records) was threatened with arrest by the Indianola police during a 2000 audit in Iowa. By the 2005 audit, Krantz et al. (2005) found that the Indianola police chief had taken more appropriate steps toward compliance. The story mentioned how the police force "had a certain degree of embarrassment at the time" (Krantz et al., 2005). This "embarrassment" sparked change toward a less authoritative and more transparent police force in Indianola as well as for other county law enforcement agencies throughout Iowa. The Californians Aware follow-up audit in 2007 on law enforcement agencies also found improvements in compliance with many agencies when compared to their 2006 audit, observing that many of the agencies mastered the essentials despite a minority of agencies' performances being incredibly poor (Public Access to Law Enforcement Information, 2007). Despite the poor performances of some agencies, other agencies found ways to increase their transparency with the aid of FOI audits after compliance gaps were located and recommendations were made for greater transparency.

Since 2005, the Canadian Newspaper Association and News Media Canada FOI audits have created change with news coverage of the audit findings being aired across Canada. In the 2017 audit, Vallance-Jones and Kitagawa recognized Nova Scotia's provincial government as providing the most user-friendly online system, while they denounced the Canadian government for failing to utilize online FOI systems. Vallance-Jones and Kitagawa (2017: 47) noted how "old ways are starting to give way" despite the slow progress to incorporate an online system for FOI requests similar to Nova Scotia's system. Now FOI regimes across Canada are following this example to promote easier access.

After the 2016 City of Vancouver FOI audit that made 12 recommendations on how FOI systems can be improved, an agreeable response came from the City Manager stating that the City will be "committed" to implementing all 12 recommendations (Johnston, 2016). Likewise, the Information and Privacy Commissioner of B.C. offered recommendations for the city to follow after auditing the City of White Rock, and the Commissioner stated that it would follow up three 
months later. McEvoy expressed confidence that the City of White Rock would achieve full compliance with the recommendations mentioned in the FOI audit (McEvoy, 2018). A similar example occurred with the audit on Australian FOI performance. The Australian National Audit Office advised that the Australian Information Commissioner publish a statement on its regulatory approach, which the government agencies that were audited signed on to. FOI audits can thus encourage governments to ensure their FOI regimes are well functioning. Beyond change in government, FOI audits could also be a vehicle for broader social change (and see Society of Professional Journalists, 2020).

\section{Discussion and conclusion}

Analyzing trends and patterns with FOI audits conducted across Canada, the United States, the United Kingdom, and Mexico, we have found four major themes. First, criminal justice and security is an impediment to access to government records across jurisdictions. Second, despite challenges, FOI audits are touted as important to working toward government transparency and accountability. Third, FOI audits have highlighted government corruption, malpractice, or scandals that are important to investigate further and that have implications for justice. Fourth, FOI audits have the capacity to influence social change in the domain of government transparency and beyond.

Despite challenges involved in accessing government records and the limits of law, FOI can have pro-democratic effects (Worthy, 2017) and feed into social movements for justice. Access to government records is an important dimension of democracy, though the access is never total and the struggle for greater access continues (Martin \& Lanosga, 2010). People can also push for changes to FOI as part of a broader mobilization involving data activism and politics. Pozen (2016) is more critical, arguing that the U.S. FOIA is a regressive, reactionary form of transparency that entrenches government power and control over records. This may be the case, and we are partial to Pozen's critique. However, this is no reason to abandon the domain of FOI laws as a way of seeking records or a way of mobilizing for transparency and justice, since there are few other ways to collect such data and the records can be used to inform social movements of any kind. Access to government records must also be situated in a social and cultural context, which should include awareness of the history of oppression and racism (van Wyk, 2019). In this way, access to information can be a form of access to justice. A genuine approach to creating open government would enhance transparency to a greater degree (Berliner et al., 2019; Beyer, 2014), however, open government in most countries is little more than rhetoric at this time since the records made available under proactive disclosure are hand-picked by political staffers or not as open as they appear (Wang \& Shepherd, 2020). Yet FOI laws remain crucial to access advocates who wish to change the relationship between citizens and government, which at this time remains mediated by secrecy and obscurity.

Despite the barriers and the challenges, which we agree are regressing further over time based on our analysis of FOI audits as well as our experience as FOI users (see Walby \& Luscombe, 2018, 2017), we argue that FOI audits are one form of access advocacy that is important to undertake but also communicate widely, not only in regards to the specific findings but also in relation to the broader politics of accessing information and data activism. As Bennett (2010) notes in his research on the privacy movement, privacy advocates vary by strategy, size of group, and the networks they are a part of. Access advocates are similarly positioned in terms of strategy, groups, and networks. As a strategy and a resource, the FOI audit is important because of its 
specific findings but also as a symbol of accountability and transparency. The audit can hook new people and groups into the movement for improved access to government records, or could politicize people to think differently about the state and government conduct. There is a need to educate more people about FOI and the possibilities of accessing government records (Weiler, 2017). Audits are another way of demonstrating benefits as well as challenges with FOI.

Finally, we think it is important that the 2000 New Mexico audit, the 2005 Iowa audit, the (Californians Aware) 2009 Sacramento Public Education Audit, and the Tennessee Public Records Policy audit in 2018 involved a participatory component. Future FOI audits should aim to be collaborative, participatory, and empowering. We know that some audits conducted by journalism professors involve students, which is already inclusive. We are envisioning a direction that is even more community-involved, and that involves multiple community stakeholders. FOI audits conducted by journalists or academics should also be inclusive of local communities impacted by the government practices or policies being investigated. FOI audits could be undertaken more along the lines of community-based research and participatory action research. This may add time and effort to the process, but it will enrich the audit by shaping the audit's request wording and focus and by hooking a greater number of community groups and citizens into the audit process, thereby revealing the interconnected nature of access advocacy and struggles for social justice. What we are pointing to is a more definite connection to be made between FOI research and social movements. The FOI audit could be a small part of quests not only for information justice, but for social and economic justice. Making audits even more participatory would also help to grow the movement for information rights and activism and help people realize how important access to government information is for everyone in society no matter their social position or status.

\section{Recommendations for FOI audits}

- Study previous audits. This will provide ideas regarding how to phrase FOI requests and what to explore. It will allow a conversation with those previous audits, increasing the scope and resonance of the work.

- Collaborate with local journalists, if possible. This would enhance the capacity of the team and perhaps increase the size and the depth of the audit. Doing so may also provide greater opportunities for getting the word out about the findings to multiple audiences, as well.

- Collaborate with local social movement groups and community groups. This will provide additional ideas for FOI requests and will boost the credibility and reach of the work.

- Communicate. Make sure to keep lines of communication open with FOI coordinators, and do so for every request in the audit. Make sure to keep lines of communication open among everyone on the team.

- Empower local social movement groups and community groups to take ownership of the audit. Doing so may invite more people to partake in government transparency initiatives and build cross-movement solidarity and empathy.

- Be creative with knowledge mobilization. A report and a story in the news are good, but consider zines, podcasts, pamphlets, and social media strategies as well. 


\section{References}

Ackerman, J., \& Sandoval-Ballesteros, I. (2006). The Global Explosion of Freedom of Information Laws. Administrative Law Review, 58, 85-130.

Administration of the Freedom of Information Act 1982, ANAO Report No.8 2017-18. Australian National Audit Office. https:/www.anao.gov.au/work/performance-audit/administrationfreedom-information-act-1982

Aldrich, R., \& Moran, C. (2019). 'Delayed Disclosure': National Security, Whistle-Blowers and the Nature of Secrecy. Political Studies, 67(2), 291-306.

Almanzar, T., Aspinwall, M., \& Crow, D. (2018). Freedom of Information in Times of Crisis: The Case of Mexico's War on Drugs. Governance, 31(2), 321-339.

Arnold, Jason. (2015). Secrecy in the Sunshine Era: The Promise and Failures of U.S. Open Government Laws. Witchita: University Press of Kansas.

Ashcroft, J. (2001). Memorandum for Heads of All Federal Departments and Agencies. https://nsarchive2.gwu.edu//NSAEBB/NSAEBB84/Ashcroft\%20Memorandum.pdf

Audits. Californians Aware. https://www.calaware.org/audits/

Audit of Access to Information and Privacy (2016). Internal Audit and Program Evaluation Directorate. CBSA. https://www.cbsa-asfc.gc.ca/agency-agence/reports-rapports/aeve/2016/atip-aiprp-eng.html

Audit of the Access to Information Process (2016). Internal Audit Services Branch, Employment and Social Development Canada. http://www12.esdc.gc.ca/sgpe-pmps/servlet/sgpppmps-pub?lang=eng\&curjsp=p.5bd.2t.1.31s@eng.jsp\&curactn $=$ dwnld\&pid $=52986 \&$ did $=4873$

Audit of Access to Information at the Canadian Space Agency, Project \# 17/18 01-04. (2018). Audit and Evaluation Directorate, CSA. https://www.asc-csa.gc.ca/eng/publications/ar1718-0104.asp\#1.1

Banton, M. (2012). Destroy? 'Migrate'? Conceal? British Strategies for the Disposal of Sensitive Records of Colonial Administrations at Independence. The Journal of Imperial and Commonwealth History, 40(2), 321-335.

Bennett, C. (2010). The Privacy Advocates: Resisting the Spread of Surveillance. Boston: MIT Press.

Berliner, D., Ingrams, A., \& Piotrowski, S. (2019). The Future of FOIA in an Open Government World: Implications of the Open Government for Freedom of Information Policy and Implementation. Villanova Law Review, 63(5), 867-894.

Beyer, J. (2014). The Emergence of a Freedom of Information Movement: Anonymous, WikiLeaks, the Pirate Party, and Iceland. Journal of Computer-Mediated Communication, 19(2), 141-154.

Birkinshaw, P. (2010). Freedom of Information: The Law, the Practice and the Ideal. 4th Edition. Cambridge: Cambridge University Press.

Blanton, T. (2010). Sunshine and Shadows: The Clear Obama Message for Freedom of Information Meets Mixed Results. The National Security Archive. https://nsarchive2.gwu.edu/NSAEBB/NSAEBB308/index.htm

Blanton, T., \& Jones, N. (2011a). Eight Federal Agencies Have FOIA Requests a Decade Old, According to Knight Open Government Survey. The National Security Archive. https://nsarchive2.gwu.edu/NSAEBB/NSAEBB349/index.htm 
Blanton, T., \& Jones, N. (2011b). Glass Half Full. The National Security Archive. https://nsarchive2.gwu.edu/NSAEBB/NSAEBB338/index.htm

Blanton, T., Fuchs, M., Adair, K., \& Nielsen, C. (2007). Agencies Violate Law on Online Information. The National Security Archive. https://nsarchive2.gwu.edu/NSAEBB/NSAEBB216/index.htm

Blanton, T., Fuchs, M., Adair, K., \& Nielsen, C. (2008). Mixed Signals, Mixed Results: How President Bush's Executive Order on FOIA Failed to Deliver. The National Security Archive. https://nsarchive2.gwu.edu/NSAEBB/NSAEBB246/index.htm

Blanton, T., Ferroggiaro, W., Fuchs, M., \& Elias, B. (2003). The Ashcroft Memo: "Drastic" Change or "More Thunder than Lightning"? The National Security Archive Freedom of Information Act Audit. The National Security Archive.

https://nsarchive2.gwu.edu/NSAEBB/NSAEBB84/FOIA\%20Audit\%20Report.pdf

Blanton, T., Fuchs, M., \& Elias, B. (2003). Justice Delayed is Justice Denied: The Ten Oldest Pending FOIA Requests, The National Security Archive Freedom of Information Act Audit. The National Security Archive. https://nsarchive2.gwu.edu/NSAEBB/NSAEBB102/tenoldest.pdf

Boye Koch, P. (2019). Promise and Practice of the Principle of Equal Access to Information in the Danish Local Administration. Central European Public Administration Review, 17(2). http://uprava.fu.uni-lj.si/index.php/CEPAR/article/view/408

Braun, V., \& Clarke, V. (2019). Reflecting on Reflexive Thematic Analysis. Qualitative Research in Sport, Exercise and Health, 11(4), 589-597.

Bronskill, J. (2017). Access to Information System Getting Worse, says Audit. https://www.macleans.ca/politics/access-to-information-system-canada-worse-trudeauharper/

Brownlee, J. (2015). Contract Faculty in Canada: Using Access to Information Requests to Uncover Hidden Academics in Canadian Universities. Higher Education, 70(5), 787-805.

Capeloto, A. (2019). Agency Perspectives on Online Public Records Request Portals. The Journal of Civic Information, 1(2), 17-44.

Capeloto, A. (2014). Transparency on Trial: A Legal Review of Public Information Access in the Face of Privatization. Connecticut Public Interest Law Journal, 13(1), 19-42.

Carroll, E. (2016). Protecting the Watchdog: Using the Freedom of Information Act to Preference the Press. Utah Law Review, 2, 193-243.

Cosh, C. (2009). Centre of the Storm. MacLean's. https://www.macleans.ca/news/canada/centreof-the-storm/

Cuillier, D. (2019). Scandals and Freedom of Information. In H. Tumber \& S. Waisbord (eds.), The Routledge Companion to Media and Scandal. London: Routledge, pp. 215-234.

Cuillier, D., \& Pinkleton, B. (2011). Suspicion and Secrecy: Political Attitudes and their Relationship to Support for Freedom of Information. Communication Law and Policy, 16(3), 227-254.

Cuillier, D. (2010). Honey v. Vinegar: Testing Compliance-gaining Theories in the Context of Freedom of Information Laws. Communication Law and Policy, 15(3), 203-229.

Darch, C., \& Underwood, P. (2005). Freedom of Information Legislation, State Compliance and the Discourse of Knowledge: The South African Experience. International Information \& Library Review, 37(2), 77-86. 
Elias, B., Blanton, T., \& Fuchs, M. (2006). A FOIA Request Celebrates its $17^{\text {th }}$ Birthday. A Report on Federal Agency FOIA Backlog. The National Security Archive. https://nsarchive2.gwu.edu/NSAEBB/NSAEBB182/

Fisher, D. et al. (2018). Public Records Policy Audit: A survey of 306 Tennessee Counties, Cities and School Districts. Tennessee Coalition for Open Government. http://tcog.info/publicrecords-policy-audit/

FOIA Audits. The National Security Archive. https://nsarchive.gwu.edu/foia/audits

Freedom of Information. News Media Canada. https://nmc-mic.ca/public-affairs/freedom-ofinformation/

Freedom of Information Compliance Audit. Freedom of Information Hawai'i. (2006). Society of Professional Journalists: Hawai'i Chapter. http://www.hawaiispj.org/foi/foiaudit.htm

Georgia Audit 2004. (2004). Gwinnett Daily Post. National Freedom of Information Coalition. https:/www.nfoic.org/georgia-audit-2004

Gilbert, J. (2000). Access Denied: The Access to Information Act and its Effect on Public Records Creators. Archivaria, 49, 84-123.

Goldberg, D. (2006). Access to Information Laws in Scotland and England: Close Freedom of Information (FOI) Encounters of the Third Kind. Comparative Media Law Journal, 8(1), 33-72.

Grigg, S., O’Sullivan, J., Goldacre, B. \& Heneghan, C. (2019). Transparency of the UK Medicines Regulator: Auditing Freedom of Information Requests and Reasons for Refusal. EBM Analysis: General Medicine Link: https://ebm.bmj.com/content/24/1/20

Grimmelikhuijsen, S., John, P., Meijer, A., \& Worthy, B. (2018). Do Freedom of Information Laws increase Transparency of Government? A Replication of a Field Experiment. Journal of Behavioral Public Administration, 1(2), 1-10.

Guy, M., \& Oberlin, M. (2009). Assessing the Health of FOIA after 2000 through the Lens of the National Security Archive and Federal Government Audits. Law Library Journal, 101, 331-353.

Hammitt, H. (2001). Access to Public Records in Connecticut: A Survey of Compliance by State Agencies with the Freedom of Information Act. https://www.state.ct.us/foi/Access_Survey/2001\%20Public\%20Access\%20Survey/Surve y\%20-\%20Section $\% 201 . h t m$

Harper, L., \& Harvey, C. (2020). How Transparent is President Trump? Audit Shows ThreeQuarters of His Decisions Have Been Bad for Openness. The National Security Archive. https://nsarchive.gwu.edu/foia-audit/foia/2020-03-13

Harper, L., Jones, N., Blanton, T., \& Reid, T. (2019). 25-Year-Old FOIA Request Confirms FOIA Delays Continue Unabated. The National Security Archive. https://nsarchive.gwu.edu/foia-audit/foia/2019-03-08/25-year-old-foia-request-confirmsfoia-delays-continue-unabated

Hazell, R., \& Worthy, B. (2010). Assessing the Performance of Freedom of Information. Government Information Quarterly, 27(4), 352-59.

Heffernan, O. (2009). Climate Data Spat Intensifies. Nature. https:/www.nature.com/articles/460787a

Johnson, B. (2020). Public Records Officers' Perspectives on Transparency and Journalism. The Journal of Civic Information, 2(1), 1-22.

Johnston, Sadhu. (2016). OIPC Audit, Letter to Commissioner. City of Vancouver. https://vancouver.ca/images/web/pdf/OIPC-audit-letter-to-commissioner.pdf 
Jones, N., \& Harper, L. (2015). Most Agencies Falling Short for Online Records. The National Security Archive. https://nsarchive2.gwu.edu/NSAEBB/NSAEBB505/

Kells, S. (2010). Thrusters, Scoopers, Scroungers and Squirrels: A Taxonomy of Public sector audit and accountability mechanisms. Journal of Contemporary Issues in Business and Government, 16(1), 1-25.

Kimball, M. (2012). Shining the Light from the Inside: Access Professionals' Perceptions of Government Transparency. Communication Law and Policy, 17(3), 299-328.

Kimball, M. (2011). Mandated State-Level Open Government Training Programs. Government Information Quarterly, 28(4), 474-483.

Kingston, S., Elliott, A., \& Thomas, T. (2018). 'Cost' Calculations as a Barrier to Gaining Information under the Freedom of Information Act 2000 from the Police in England and Wales. Policing and Society, 29(7), 834-847.

Krantz, C. et al. (2005). Records hard to get in Warren County. The Des Moines Register. https://www.nfoic.org/iowa-audit-march-2005

Lagunes, P., \& Pocasangre, O. (2019). Dynamic Transparency: an Audit of Mexico's Freedom of Information Act. Public Administration, 97(1), 162-176.

https://onlinelibrary.wiley.com/doi/full/10.1111/padm.12553

Lupick, T. (2016). Audit Finds City of Vancouver Failing to meet FOI Deadlines and likely Deleting Emails. The Georgia Straight. https://www.straight.com/news/724566/auditfinds-city-vancouver-failing-meet-foi-deadlines-and-likely-deleting-emails

Luscombe, A. and K. Walby. (2017). Theorizing Freedom of Information: the Live Archive, Obfuscation, and Actor-Network Theory. Government Information Quarterly, 34(3), 379387.

Martin, S. E., \& Lanosga, G. (2010). The Historical and Legal Underpinnings of Access to Public Documents. Law Library Journal, 102(4), 613-634.

Massey, B. (2000). New Mexico Public Records Access Audit. Associated Press. https://www.nfoic.org/sites/default/files/nmaudit.pdf

McEvoy, M. (2018). Audit \& Compliance Report F18-02: City of White Rock, Duty to Assist. Office of the Information \& Privacy Commissioner for British Columbia.

Michener, G. (2015). Assessing Freedom of Information in Latin America a Decade Later: Illuminating a Transparency Causal Mechanism. Latin American Politics and Society, 57(3), 77-99.

Michener, G. (2011). FOI Laws around the World. Journal of Democracy, 22(2), 145-159.

Mulvey, R., \& Valvo, J. (2019). Opening the State House Doors: Examining Trends in Public Access to Legislative Records. The Journal of Civic Information, 1(2), 17-44.

Nader, R. (1970). Freedom from Information: The Act and the Agencies. Harvard Civil Rights / Civil Liberties Law Review, 5, 1-55.

News Media Canada. (2010). 2009-2010 FOI Audit. https://nmc-mic.ca/public-affairs/freedomof-information/2009-2010-foi-audit/

News Media Canada. (2006). 2006 FOI Audit. https://nmc-mic.ca/public-affairs/freedom-ofinformation/2006-foi-audit/

News Media Canada. (2005). 2005 FOI Audit. https://nmc-mic.ca/public-affairs/freedom-ofinformation/2005-foi-audit/

2011 State Agencies Audit. (2011). Californians Aware. https://www.calaware.org/audits/2011state-agency-follow-up-audit/results-overview/ 
Nielsen, C. (2007). 40 Years of FOIA, 20 Years of Delay: Oldest Pending FOIA Requests Date Back to the 1980s. The National Security Archive. https://nsarchive2.gwu.edu/NSAEBB/NSAEBB224/ten_oldest_report.pdf

Phillips, E., \& Dill, M. (2019). Access to Information in Administrative Tribunals: Toronto Star v. the Attorney General of Ontario. Canadian Journal of Administrative Law \& Practice, $32(1), 45-55$.

Potolsky, M. (2019). The National Security Sublime: On the Aesthetics of Government Secrecy. London: Routledge.

Pozen, D. (2016). Freedom of Information Beyond the Freedom of Information Act. University of Pennsylvania Law Review, 165, 1097-1158.

Public Access to Law Enforcement Information. (2007). Californians Aware. https://www.calaware.org/audits/2007-law-enforcement-audit-follow-up/audit-report/

Read, J. Harrop, C. Geekie, J. and Renton, J. (2018). An audit of ECT in England 2011-2015: Usage, Demographics, and Adherence to Guidelines and Legislation. Psychology and Psychotherapy, 91(3), 263-277.

Roberts, A. (2006). Blacked Out: Government Secrecy in the Information Age. Cambridge: Cambridge University Press.

Roberts, A. (2002). Administrative Discretion and the Access to Information Act: an "Internal Law" on Open Government? Canadian Public Administration, 45(2), 175-194.

Rowat, D. (1993). Freedom of Information: The Appeal Bodies under the Access Laws in Canada, Australia, and New Zealand. Australian Journal of Public Administration, 52, 215-221.

Roziere, B. and K. Walby. Freedom of Information and the Duty to Assist in Canada. Forthcoming with Canadian Public Administration.

Sacramento Area Public Schools, Higher Ed Campuses Get Low Sunshine Grades. (2009). Californians Aware. https://www.calaware.org/audits/2009-sacramento-area-publiceducation-audits/

Saez-Martin, A., Caba-Perez, C., \& Lopez-Hernandez, A. (2017). Freedom of Information in Local Government: Rhetoric or Reality? Local Government Studies, 43(2), 245-273.

Sheaff, M. (2019). Secrecy, Privacy \& Accountability: Challenges for Social Research. London: Palgrave.

Shepherd, E., Stevenson, A., \& Flinn, A. (2010). Information Governance, Records Management, and Freedom of Information: A Study of Local Government Authorities in England. Government Information Quarterly, 27(4), 337-345.

Society of Professional Journalists (2020). FOI Toolkit and Audit Resources.

https://www.spj.org/foitoolkit.asp

The Disclosure of Climate Data from the Climatic Research Unit at the University of East Anglia. Eighth Report of Session 2009-2010. (2010). House of Commons Science and Technology Committee. https://publications.parliament.uk/pa/cm200910/cmselect/cmsctech/387/387i.pdf

Vallance-Jones, F., \& Kitagawa, E. (2017). 2017 National Freedom of Information Audit. News Media Canada. https://nmc-mic.ca/wp-content/uploads/2017/09/2017-National-Freedomof-Information-Audit_final.pdf

Vallance-Jones, F., \& Kitagawa, E. (2015). National Freedom of Information Audit 2015. News Media Canada. https://nmc-mic.ca/sites/default/files/FOI-2015-FINAL.pdf 
Vallance-Jones, F. (2014). National Freedom of Information Audit 2014. News Media Canada. https://nmc-mic.ca/sites/default/files/FOI2014-FINAL.pdf

Van Wyk, T. (2019). Accessing Information in South Africa. In Walby, K. and A. Luscombe (eds), Freedom of Information and Social Science Research Design. New York: Routledge, pp. 24-37.

Wagner, A. (2017). Essential or Extravagant: Considering FOIA Budgets, Costs and Fees. Government Information Quarterly, 34(3), 388-395.

Walby, K. and Luscombe, A. (2018). Ethics Review and Freedom of Information Requests in Qualitative Research. Research Ethics, 14(4), 1-15.

Walby, K. and A. Luscombe. (2017). Criteria for Quality in Qualitative Research and Use of Freedom of Information Requests in Social Research. Qualitative Research, 17(5), 537553.

Wang, V., \& Shepherd, D. (2020). Exploring the Extent of Openness of Open Government Data: A Critique of Open Government Datasets in the UK. Government Information Quarterly, 37(1). https://www.sciencedirect.com/science/article/pii/S0740624X18302764

Wasike, B. (2016). FoIA in the Age of "Open.Gov": An Analysis of the Performance of the Freedom of Information Act under the Obama and Bush Administrations. Government Information Quarterly, 33(3), 417-426.

Weiler, M. (2017). Legislating Usability: Freedom of Information Laws That Help Users Identify What They Want. Journal of International Media \& Entertainment Law, 7(1), 101-127.

Worthy, B. (2017). The Politics of Freedom of Information: How and Why Governments Pass Laws that Threaten their Power. Manchester: Manchester University Press.

Worthy, B., John, P., \& Vannoni, M. (2017). Transparency at the Parish Pump: A Field Experiment to Measure the Effectiveness of Freedom of Information Requests in England. Journal of Public Administration Research and Theory, 27(3), 485-500.

Yeager, M. (2006). The Freedom of Information Act as a Methodological Tool: Suing the Government for Data. Canadian Journal of Criminology and Criminal Justice, 48(4), 499-521. 